\title{
PROUST E O CADAFALSO DE CAMUS: A "FESTA DA VELHICE" E $O$ "SOBRE A LEITURA"
}

\author{
Luciana Persice Nogueira*
}

\begin{abstract}
Resumo: O artigo de Albert Camus "A inteligência e o cadafalso" trata do classicismo literário francês e elege a cena do "bal de têtes", de Le temps retrouvé de Marcel Proust, como um dos grandes momentos do romance francês. Essa cena é abordada aqui segundo a perspectiva camusiana, e em função dos conceitos e imagem desenvolvidos no artigo: repetição, inteligência, e cadafalso. Em seguida, a imagem do cadafalso é estendida ao momento de início de reviravolta na carreira de Proust, quando da escritura e da publicação de seu artigo "Sur la lecture", que anuncia páginas que se tornarão antológicas em "Combray".
\end{abstract}

Palavras-chave: Proust; Camus; crítica literária; classicismo.

\begin{abstract}
Albert Camus's article "L'intelligence et l'échafaud" is on French literary classicism and elects the scene known as the "bal de têtes", of Marcel Proust's Le temps retrouvé, as one of the great moments of French novel. This scene is approached here according to Camus' perspective and the concepts and image he develops in his article : repetition, intelligence, and scaffold. Then, the image of the scaffold is extended to the beginning of the turning point in Proust's carrier, when he writes and publishes his article "Sur la lecture", which announces some pages that will become memorable in "Combray".
\end{abstract}

Key-words: Proust; Camus; literary criticism; classicism.

* Universidade Federal do Rio de Janeiro. 
Quando se fala no classicismo literário francês, costumase fazer referência ao "gênio" nacional que privilegia o "goût" francês, um certo gosto pela ordem, pela elegância, pela harmonia, concatenadas consoante um delicado senso de equilíbrio, regido pelo autodomínio e pela disciplina da forma, e expresso através da unidade, da simplicidade e da clareza - essa foi a meta formal que os autores do século XVII francês impuseram à sua arte, e que passou a ser a concepção corrente do termo na história literária francesa (que servirá de baliza aqui). Albert Camus retoma a questão da tradição clássica da literatura francesa em seu artigo "A inteligência e o cadafalso". ${ }^{1}$ Sem romper totalmente com a abordagem habitual, o escritor, aqui crítico literário, desenvolve reflexões que abrem novas perspectivas ao entendimento do classicismo e enfoca um elemento, ou, mais precisamente, uma estratégia escritural, que funciona como conceito norteador ao longo do artigo e que ele considera como fulcral no grande romance francês: a repetição.

Camus inaugura seu artigo com uma anedota, que passa a valer como metáfora do processo escritural, a partir do qual se explanam dois conceitos mestres de seu ensaio: a "inteligência" e o "cadafalso":

On dit que Louis XVI, sur le chemin de la guillotine, ayant voulu charger un de ses gardiens d'un message pour la reine, s'attira cette réponse "Je ne suis pas ici pour faire vos commissions, je suis ici pour vous conduire à l'échafaud". Ce bel exemple de propriété dans les termes et l'obstination dans l'emploi, me paraît s'appliquer parfaitement, sinon à toute notre littérature romanesque, du moins à une certaine tradition classique du roman français. Les romanciers de cette famille se refusent aux commissions et leur seul souci semble être de mener imperturbablement leurs personnages au rendez-vous

\footnotetext{
${ }^{1}$ Publicado inicialmente na revista Confluences, n. 21-24, 1943, dedicada aos "problemas do romance".
} 
qui les attend, que ce soit la maison de retraite de Mme de Clèves, le bonheur de Juliette ou la déchéance de Justine, l'échafaud de Julien Sorel, la solitude d'Adolphe, le lit de mort de Mme de Graslin ou cette fête de la vieillesse que découvre Proust dans le salon de Mme de Guermantes. Ce qu'ils ont en propre, c'est l'unité de l'intention. (CAMUS, 2006, p. 894-895) ${ }^{2}$

A pungente imagem do rei sendo levado ao cadafalso é comparada ao momento intenso em que o escritor é levado, "imperturbavelmente", ao "compromisso que o aguarda": realizar/executar seu projeto literário conduzindo história(s) e personagem(ns) ao destino previamente traçado em função desse projeto. E a inteligência é a economia do texto, a trama engendrada que coloca em ação personagens e conceitos.

Sem chegar a negar a ideia de "goût" (Camus fala em "elegância que ainda está por ser definida” (CAMUS, 2006, p. 895)), o crítico considera que "a simplicidade profunda e o classicismo" do texto literário não estão na busca de uma forma perfeita (apolínea), mas sim “alhures” (CAMUS, 2006, p. 896). Para o autor, a veia clássica francesa consiste, sobretudo, numa unidade de intenção (que, portanto, predomina sobre a forma), e a simplicidade se manifesta como "fixidez de intenção". A intenção

2 "Dizem que Luis XVI, no caminho para a guilhotina, tendo querido encarregar um de seus guardas de enviar uma mensagem à rainha, obteve essa resposta: 'Não estou aqui para dar os seus recados, estou aqui para conduzi-lo ao cadafalso'. Esse belo exemplo de correção lexical e da obstinação em exercê-la, parece-me aplicar-se perfeitamente, mesmo que não a toda a literatura romanesca, ao menos a uma certa tradição clássica do romance francês. Os romancistas dessa família recusam-se a dar recados e sua única preocupação parece ser encaminhar, imperturbavelmente, seus personagens ao compromisso que os aguarda, seja ele a casa de repouso de Mme de Clèves, a felicidade de Juliette ou a desgraça de Justine, o cadafalso de Julien Sorel, a solidão de Adolfo, o leito de morte de Mme de Graslin, ou aquela festa da velhice que Proust descobre no salão de Mme de Guermantes. O que eles possuem, é a unidade da intenção". (Tradução minha). 
seria uma espécie de ideia fixa, e o romance francês, dentro dessa perspectiva, pode ser qualificado como "obstinado" - a um só tempo "obstiné" e "entêté" ("teimoso") (CAMUS, 2006, p. 891892 ) - justamente na medida em que se reconhece a unidade e a simplicidade que lhe são inerentes.

Quanto à forma, a prosa está "a meio caminho entre a monotonia e a tagarelice", na busca da "relação precisa entre o tom e o pensamento" (CAMUS, 2006, p. 892). Não deixa de ser uma outra maneira de falar no ideal de equilíbrio ou simetria, tão tipicamente clássicos, mas Camus privilegia a fina harmonia da "tradução do que se sente e do que se quer fazer sentir" (CAMUS, 2006, p. 896), realizada através do que o crítico qualifica de "monotonia apaixonada" (CAMUS, 2006, p. 897), e que constitui o cerne sua análise: a questão da repetição.

"Ser clássico", diz Camus, "é repetir-se e saber se repetir" (CAMUS, 2006, p. 897). Nesse momento, fica mais claro por que o escritor inclui Marcel Proust no panteão dos clássicos e elege sua "festa da velhice" como um dos grandes momentos do romance francês.

A "festa da velhice" corresponde ao trecho de Le temps retrouvé conhecido como "le bal de têtes" ("baile de máscaras"). Essas páginas apoteóticas do último volume de À la recherche du temps perd $u$ descrevem o reencontro de Marcel com conhecidos d'antanho, por ocasião de uma reunião social onde convivem diversas gerações, distintos grupos sociais (os aristocratas e os burgueses dos dois caminhos da geografia idealizada de Combray, cidade da infância do herói), aglutinados, ora camuflados (a ação do tempo sobre os rostos dos convidados funcionando como máscara), ora desvendados pelo olhar pasmo e aguçado do herói, também ele, envelhecido.

Nesse sentido, de fato, a "festa da velhice" de Le temps retrouvé é o "compromisso que aguarda o herói” ao final de tantos tomos, de tantas histórias emaranhadas e superpostas umas às outras, que, em mais uma entre tantas inversões proustianas, ao 
invés de representar um estilo precioso e confuso (crítica que o autor recebeu de seus contemporâneos), é expressão do mais tradicional classicismo francês.

De maneira muito esquemática, pode-se dizer que Proust escreve de maneira espiralada, por circunvoluções, retomando temas e conferindo-lhes novos ângulos, acrescidos de perspectivas inauditas, por meio de revelações (inclusive no sentido fotográfico, num acúmulo de clichês), digressões, remissões internas, citações a outros textos (imiscuindo autores e obras), infundindo contornos imprecisos (ou confusos, para seus críticos contemporâneos), por demais extensos (ou cansativos), sinuosos (ou labirínticos)... num flagrante desvio com relação às preconizadas concisão e clareza clássicas.

Representativo do estilo proustiano, o "bal de têtes" é um trecho longo que tem início no momento em que o herói adentra o salão, depois da cena conhecida como "Adoração perpétua", em que Marcel vivencia um primeiro reencontro impactante com a vocação artística (com a redescoberta da leitura de infância, por acaso, entre os volumes da biblioteca dos Guermantes). E, ao longo das páginas, o herói caminha, entre sustos e assombros, em meio a velhos conhecidos, antigas lembranças, reflexos e reflexões, que revitalizam a memória e incutem o desejo de escrever e descrever o fantasmagórico espetáculo do lapso do tempo e do colapso dos homens.

Mas há, no texto, um momento fulcral, que prepara para o fim da cena e do próprio romance, que começa com a visão inesperada da chegada de Mlle Saint-Loup. Essa jovem - filha de Gilberte, primeiro amor de Marcel, neta de Swann e Odette - será, para o narrador, uma "encruzilhada" para onde convergem muitas das linhas da trama da Recherche.

Na tradução de Fernando Py, para quem Le temps retrouvé é $O$ tempo recuperado, o texto é como segue:

Essa filha, cujo nome e fortuna podiam fazer a mãe esperar que desposasse um príncipe real e coroasse 
toda a obra ascendente de Swann e de sua mulher, casou-se mais tarde com um obscuro literato, pois não tinha nenhum esnobismo (...) Como a maioria dos seres, aliás, não representaria ela na vida o mesmo papel que, nas encruzilhadas, fazem as "clareiras" onde convergem as estradas vindas, igualmente na nossa vida, dos mais diversos pontos? No meu caso, eram numerosas aquelas que levavam à Srta. de Saint-Loup e se irradiavam a seu redor. E, acima de tudo, vinham terminar nela os dois grandes "lados", ou caminhos, onde eu tanto havia passeado e feito tantas fantasias ... Já se estabeleciam transversais entre essas duas estradas... Nova transversal aqui... teve razão o poeta em falar dos "fios misteriosos" que a vida rompe. Mas ainda é mais verdadeiro que ela os tece sem cessar entre as criaturas, entre os acontecimentos, que entrecruza tais fios, que os redobra a fim de reforçar a trama, de modo que entre o menor ponto do nosso passado e todos os demais uma opulenta rede de lembranças nos dá uma variada escolha de comunicações... E, para melhor fundir todos os meus passados, a Sra. Verdurin, exatamente como Gilberte, havia desposado um Guermantes. Não poderíamos descrever nossas ligações, ainda raras, com alguém, sem evocar os mais diversos locais da nossa vida. Assim, cada indivíduo - e eu mesmo era um deles - proporcionava-me a medida da duração pelo giro que havia cumprido não só em torno de si mesmo, mas em torno aos outros, e notadamente pelas posições que ocupara sucessivamente em relação a mim. E, sem dúvida, todos esses planos diferentes segundo os quais o Tempo, desde que eu acabava de recuperá-lo nessa festa, dispunha a minha vida, fazendo-me pensar que, num livro em que desejaria contar uma vida, seria preciso empregar, por oposição à psicologia plana que se usa de ordinário, uma espécie de psicologia no espaço, acrescentavam uma nova beleza a essas ressurreições que minha memória operava enquanto eu me entregava ao devaneio, a sós, na biblioteca, visto que a memória, introduzindo o passado no presente sem modificá-lo, 
tal qual fora quando presente, suprime exatamente essa enorme dimensão do Tempo conforme a qual a vida se realiza. (PROUST, [1997])

A quantidade de temas aqui condensados chega a ser desnorteante: a história de Swann e Odette (todo um tomo da obra); o futuro casamento com o "obscuro literato" (que pode ser o próprio narrador, ou sua hipóstase, em mais uma confusão entre herói e narrador); o esnobismo; os "dois caminhos" (de Combray, mas que simbolizam tantos antagonismos); os múltiplos fios (da intrincada trama do romance, mas também das inúmeras e incalculáveis citações, explícitas ou não no texto; os "fios misteriosos" referem-se à "Tristesse l'Olympio" de Victor Hugo) que permitem transversalidades entre os dois caminhos que, afinal, não são estanques (a revelação de que havia um caminho comunicante entre os de Méséglise e de Guermantes fora feita por Gilberte, em Albertine disparue, numa primeira camada de transversalidade; a compreensão paulatina dessa comunicabilidade é um entendimento poético da existência e da arte, além de representar a constatação das transformações sociais ocorridas no tempo vivido e no espaço percorrido pelo narrador); a "fusão dos passados" do narrador/herói, do sentido construído a partir de sua visão dos fatos e dos seres ao seu redor, no movimento do "giro cumprido ao redor de si mesmo e dos outros" - num retorno ao incipit da obra, em que Marcel se encontra no interior de seu quarto, na casa da infância, e o narrador afirma, em frase, também ela, clássica: "Quando um homem está dormindo tem em torno, como um aro, o fio das horas, a ordem dos anos e dos mundos..." (PROUST, [1992]) em uma das incontáveis remissões à própria Recherche.

O trecho selecionado acima termina com temas centrais da obra proustiana: o Tempo, a psicologia no espaço, a memória, e o livro a ser escrito. Tudo isso dentro do padrão escritural assinalado por Camus como sendo característico do classicismo francês: a repetição, o saber repetir, dentro de uma "monotonia 
apaixonada" que exprime uma ideia fixa, em retomadas sucessivas, mas diversificadas, do mesmo tema, que reaparece, a cada vez, distinto, surpreendente, mais completo, complexo, como nas voltas de uma espiral que gira em torno de um eixo.

A decantada "festa da velhice" constitui, assim, um instrumento de observação dos múltiplos passados, das muitas situações, das intermináveis ressurreições do narrador, dos personagens e dos fatos, repetidamente reexaminados sob um novo olhar, como quando se gira um caleidoscópio e se vêem os mesmos fragmentos de maneira diferente, em nova composição.

Proust fez de sua "festa" um cadafalso, no sentido da imagem camusiana: palco do encontro inexorável consigo mesmo, com o próprio destino, execução da vocação artística e promessa virtual da obra que, ao terminar, aponta para seu reinício. Festa que enfeixa uma trama, que o escritor tece por meio de repetições obstinadas, retornando, teimosamente, sobre si mesma, ensimesmada. Servindo-se da multiplicidade das situações, converge e aponta para a unidade de sua intenção, de seu propósito, a fixidez essencial e paradoxal do texto, revelada, na cacofonia da tagarelice dos eventos, como se revelara a sonata de Vinteuil - outro tema recorrente e multifacetado da obra: pano de fundo, pilar fundamental, aspecto singular que, nas palavras de Camus, busca a "relação precisa entre o tom e o pensamento". Essa tagarelice ou sonoridade obsessiva, monótona, mas fascinante, justifica a sucessão de tomos, a realização da obra, e permite ao autor "traduzir o que sente e o que quer levar a sentir" (CAMUS, 2006, p. 896).

Finalmente, sob a ótica de "A inteligência e o cadafalso", Proust é, talvez, o melhor exemplo do classicismo francês (embora Mme Lafayette e La princesse de Clèves ocupem a maior parte do ensaio). Camus diz que "é preciso ser dois quando se escreve" (CAMUS, 2006, p. 896) - e Proust, de fato, é, às vezes, três, em função do momento do texto (autor, narrador e/ou personagem) e, para exemplificar essa ideia, comenta: 
On retrouverait aisément chez Sade, chez Stendhal, Proust, et quelques rares contemporains, l'enseignement d'un style de vie, fort différent pour chacun, mais toujours fait d'un choix, d'une indépendance calculée et d'une chasse clairvoyante. L'entêtement dans le péché devenu légitime chez Sade, les litanies de l'énergie chez Stendhal, l'ascèse héroïque de Proust pour repétrir la détresse humaine dans une existence tout entière privilégiée, ils ne disent tous qu'une chose et ils ne disent rien d'autre. D'un sentiment unique qui les a pour toujours envahis, ils font une oeuvre aux visages à la foi différents et monotones.

(...) [Ce qui fait la rigueur, la pureté, la force rentrée de cette littérature romanesque c'] est l'obstination ajustée au ton qui lui convient, la consistance d'âme qui s'y rattache, la science littéraire et humaine du sacrifice. Un tel classicisme est fait de partis pris. Ce culte de l'intelligence efficace autant qu'un art fait une civilisation et un savoir-vivre. (CAMUS, 2006, p. 899) ${ }^{3}$

Portanto, Camus, não se preocupa com o aspecto formal do classicismo (ideal de concisão, frases límpidas, estilo claro, palavras e estrutura geral simples, dentro de uma definição tradicional, de manual escolar, que tanto se vê em ensaios acadêmicos), mas com o que considera como nodal na arte

3 "Encontrar-se-ia, facilmente, em Sade, Stendhal, Proust e alguns outros raros contemporâneos, o ensinamento de um estilo de vida, muito diferente para cada qual, mas sempre feito de uma escolha, de uma independência calculada e de uma perseguição clarividente. A cisma com o pecado, tornado legítimo em Sade, as litanias da energia em Stendhal, a ascese heroica em Proust, ao reviver a aflição humana numa existência, em sua totalidade, privilegiada, nos dizem, todos, apenas uma coisa, sem dizer nada além. De um sentimento único que os invadiu para sempre, eles realizam uma obra com semblantes, a um só tempo, diferentes e monótonos. (...) [O que faz o rigor, a pureza, a força internalizada dessa literatura romanesca] é a obstinação ajustada ao tom que lhe convém, a constância d'alma que lhe é inerente, a ciência literária e humana do sacrifício. Tal classicismo é feito de ideias preconcebidas. Esse culto da inteligência eficaz, assim como uma arte, faz uma civilização e um bem-viver." (Tradução minha). 
clássica, ou seja, sua dinâmica interna: o "culto da inteligência eficaz": a decisão precisa, premeditada e calculada de perseguir, de maneira produtiva e produtora, a expressão de um "sentimento único", obsessivo, recorrente, traduzido pelo tom certo, delicado e singular, que o transmite, e o faz ecoar junto ao leitor.

O conceito de repetição clássica é, assim, surpreendente: alça a "ideia fixa" e a "monotonia" ao patamar positivo de economia de texto, assimilando-as ao "culto de uma inteligência eficaz": é nas ressurgências e insistências do tom característico do autor, ao longo de sua obra, que o "sentimento único" que o habita, permeia e anima a sua escritura, e se revela ao leitor.

Camus erige a imagem do cadafalso, palco revolucionário por excelência, onde se encenam intrigas e acertos de contas metáfora prolífica do processo criativo e escritural, em que o autor clássico retraça, reencena, trilha pela enésima vez o percurso já conhecido, mas que, ao ser retomado, revela, diferentemente, o mesmo, como quem diz, ciclicamente: "O rei morreu. Viva o rei!".

Proust era "muitos", pelo menos dois, quem sabe três, desdobrando-se para escrever sua obra. Passou toda a vida literária buscando ser fiel ao tom ou som interior, à sua necessidade pessoal de realizar uma obra de peso e respeito; encontrou o caminho somente depois de abandonar o esboço de Contre Sainte-Beuve e iniciar a redação de Du côté de chez de Swann (primeiro dos sete volumes de À la recherche du temps perdu). Como diz Camus, "revive a aflição humana". Reencena a deperdição das coisas e dos seres, exalta-se com a ação devastadora da passagem do tempo, e a enxerga nos estragos do espaço ao seu redor. Registra, entre cadernos, folhas avulsas, papelotes colados às margens $\mathrm{e}$ anotações no verso e pelas beiradas das páginas, obstinadamente, o sentimento de envelhecimento, a sensação de perda e os pensamentos que esses desencadeiam.

A Recherche é uma obra colossal, clássica e repetitiva, testemunha da teimosia de um grande escritor, concentrada numa festa às avessas - como é a execução de um rei. 


\section{O outro cadafalso de Proust: "Sobre a leitura"}

A multiplicidade proustiana inclui, além da pletora de temas e de tomos, a variedade de vocações. Proust não era só romancista, mas, igualmente, crítico de arte. Escreve artigos, crônicas e ensaios, que publica em jornais e revistas especializadas. Aliás, faz de sua obra ficcional um gênero híbrido, entremeado de noções estéticas e de teoria literária (além de incluir elementos de registro histórico e de autobiografia).

Os trechos em que comenta o classicismo e os clássicos, ao longo de toda a sua obra, são inúmeros. Mas um de seus artigos mais aclamados pela crítica, "Sur la lecture", traduzido para o português literalmente como "Sobre a leitura", contém reflexões gerais sobre a leitura e, entre outros tópicos específicos, a importância dos clássicos. Esse artigo permite a Proust reencenar sua rentrée no quadro artístico, literário e intelectual da época sobre novas bases. Pois seu primeiro título, Les plaisirs et les jours, coletânea de poemas em prosa, foi um fracasso editorial e rendeu ao autor a pecha de escritor medíocre. Cabem, aqui, algumas precisões, para que se possa contextualizar a questão do clássico dentro da produção literária de Marcel Proust.

Entre o escritor medíocre de Les plaisirs et les jours (1896) e o monstro sagrado de À la recherche du temps perdu (1913-1927 - os últimos tomos sendo póstumos), há como que um abismo, um hiato. Entre os dois títulos ficcionais publicados em vida, há um lapso de dezessete anos, em que Proust realiza suas duas traduções de títulos do escritor, pensador e esteta britânico John Ruskin (1819-1900), e inicia e abandona dois projetos ficcionais: Jean Santeuil (1895-1899) e Contre Sainte-Beuve (1907-1909) deixados incompletos e fragmentários, mas que serão publicados postumamente, e dos quais muitos trechos e elementos poderão ser reconhecidos ao longo dos tomos da Recherche.

Durante esse lapso, ou limbo ficcional, Proust estuda apaixonadamente a obra de Ruskin e realiza as suas traduções. Assim como a prosa proustiana será híbrida, entre vários gêneros, 
a tradução proustiana será, também ela, híbrida: Proust vai criar um rico mosaico de erudição e o sobrepõe ao de Ruskin (escritor, como Proust, muito criticado por seus contemporâneos pelas digressões eruditas, excessivas e abundantes, que enxerta em seus escritos) e, sem qualquer moderação, ao longo do texto traduzido, implanta comentários, críticas e, por vezes, censuras ao que está traduzido, misturando, por meio de inúmeras notas, suas próprias observações teóricas, comentários autobiográficos e remissões a outras obras, tanto de Ruskin quanto dos autores ou artistas que este analisa. O conjunto dos comentários - entre prefácios, notas aos prefácios e notas aos livros de Ruskin - é, hoje, na França, mais importante do que o corpo do texto traduzido.

Os comentaristas da época vão receber com certa severidade as duas traduções, embora a segunda seja mais bem aceita. A primeira, La bible d'Amiens (1904) foi alvo de muitas críticas (particularmente no tocante à própria qualidade técnica da tradução). A segunda, Sésame et les lys (1906), embora não tenha escapado ilesa ao crivo, angariou, sobretudo, louvores. Este livro é composto de duas conferências: "Sésame. Les trésors des rois" e "Les Lys des jardins des reines". "Sésame" é sobre "como e por que ler", e visou financiar a construção de uma biblioteca pública (inglesa). "Les Lys" é sobre a educação das jovens, e foi proferida com o intuito de angariar fundos para a criação de uma escola pública (na Inglaterra).

"Sobre a leitura" é um dos textos prefaciais da edição francesa de Sésame et les lys, e é, talvez, o maior responsável pela boa aceitação desse título junto ao público leitor da época. Um dos maiores estudiosos da obra de Proust, Antoine Compagnon, afirma (na Introdução que acompanha a reedição do artigo em publicação separada) que, nesse livro, Ruskin realiza um "manifesto reformista quase socialista" (COMPAGNON, 1987, p. 14) que prega a educação popular. A partir de 1895, o Bulletin de l'union pour l'action morale, publicara trechos da segunda conferência que constitui o livro, que tiveram alguma importância no contexto do Caso Dreyfus e do movimento pela solidariedade; esse movimento 
na França, porém, é laico, e leva à separação entre a Igreja e o Estado (em 1905; Proust escreve "La mort des cathédrales", publicado no Figaro, contra essa separação iminente). O caráter evangelizador e moralizante do texto, portanto, não encontrou eco na intelectualidade francesa. Compagnon encerra sua Introdução admitindo que não entende a razão que levou Proust a traduzir esse título que, evidentemente, não é "atraente" para o público francês.

"Sobre a leitura" tem uma vocação ensaística e autônoma nítida, que se revela desde o princípio: é publicado como artigo na revista Renaissance latine um ano antes da publicação do livro traduzido; e, em 1919, é reeditado numa coletânea de ensaios (Pastiches et mélanges, pela Nouvelle Revue Française, depois de receber do autor pequenas modificações de aparência anódina). A publicação do livreto com introdução de Antoine Compagnon comprova essa vocação (ele será traduzido para o português, também em livretos, tanto no Brasil quanto em Portugal).

Essa independência do artigo com relação ao texto é, acredito, por si só, reveladora, respondendo à indagação de Antoine Compagnon e denunciando a antiguidade do projeto de traduzir Sésame et les lys: entre 1895 e 1903, Proust lê trechos dessa obra no Bulletin de l'union pour l'action morale, portanto, justo no momento em que amarga o fracasso de Les plaisirs et les jours. Entra em contato com um dos temas caros a Ruskin, que se tornará um dos assuntos mais importantes na sua futura obra: a leitura. Apesar de uma simpatia ou até empatia inicial por Ruskin, Proust vai discordar da visão do esteta britânico quanto à abordagem da questão. Ao se propor a refazer, na íntegra, a tradução de Sésame et les lys, é possível que Proust esteja tentando promover sua visão pessoal da leitura, servindo-se do suporte, ou pretexto, do livro traduzido como veículo para a edição de sua tese, ao mesmo tempo em que se aproveita da voga que a obra de Ruskin conheceu na França até o final da primeira década do século XX. Efetivamente, ao traduzir e criticar Ruskin, Proust começa a reverter sua imagem de escritor medíocre junto 
aos seus pares, auferindo, com o sucesso gradual de seu texto, reconhecimento e prestígio - que permitirão, ulteriormente, um novo olhar sobre a obra ficcional por vir.

"Sobre a leitura" contém momentos de prosa poética que são aclamados, e que se reconhecerão, e aplaudirão, depois, em "Combray", onde predominam as recordações de infância (que também se descobrirão postumamente em Jean Santeuil e Contre Sainte-Beuve), em que Proust fala da casa, do jardim, do Capitão Fracasso e da importância de sua leitura.

Esse prefácio contém, entre reminiscências e digressões, a tese de Proust sobre a leitura, que se desdobra em vários aspectos, mas que se tornará uma verdadeira obsessão ao longo de sua obra ficcional. ${ }^{4}$ Ele é inaugurado com o que Proust denomina de sua "crítica indireta à doutrina de Ruskin": o ponto de discordância que vai balizar essa crítica está no fato de que Ruskin considera a leitura como uma "conversa" com os livros, com os autores, com a "Sociedade dos mortos", que deve ter uma função preponderante na vida do leitor (dentro de uma perspectiva moralizante); nesse sentido, sua ótica não é distinta da de Descartes. Proust define a leitura como "um ato psicológico original", uma comunicação com um outro pensamento que ocorre na solidão e, portanto, mediante a total manutenção do poder intelectual do leitor; é o "milagre fecundo" da passagem de um saber, em que o saber do autor termina onde começa o do leitor (não há, portanto, diálogo); há uma sucessão no tempo, não uma concomitância. O escritor cria impressões e aparências; cria, em suma, "uma visão" ("essa

\footnotetext{
${ }^{4}$ Proust falará repetidamente, reiteradamente, sobre a leitura em geral e as leituras da infância em particular, já emJean Santeuil (os fragmentos que tratam diretamente ou indiretamente da leitura são vários: "Lectures", "Capitaine Fracasse", "Lecture et farniente sur la plage", entre outros. Anteriores, portanto, à sua tradução de Sésame et le lys e seus comentários e prefácio a ela, esses fragmentos serão transplantados ou transformados tanto em Contre SainteBeuve quanto, e principalmente, na Recherche). Em seguida, esboça algumas questões dessa tese entre as notas da tradução de Bible d'Amiens - fazendo um primeiro nexo direto entre o tema e o seu inspirador, John Ruskin.
} 
coisa, de algum modo, sem espessura, miragem estática sobre uma tela" que "nossos olhos ávidos gostariam de penetrar" (PROUST, 2011 , p. 35)), e essa visão tem por função dizer ao leitor: "olha, olha... aprende a ver!". E, nesse momento, ela "desaparece. Este é o preço da leitura e esta é a sua insuficiência. É dar um papel muito grande ao que não é mais que uma iniciação para uma disciplina. A leitura está no limiar da vida espiritual; ela pode nela nos introduzir, mas não a constitui" (PROUST, 2011, p. 36). Ela leva a uma iniciação, mas não é a iniciação; o que, para o autor, são "Conclusões", são "Incitações" para o leitor.

Proust vai falar da leitura, também, do ponto de vista dos "distúrbios do sistema nervoso": ela permitiria aos que perderam "o poder de pensar por si próprios e de criar", ressuscitarem o poder criativo, atuando como um "impulso". A esse propósito, Proust cita Les maladies de la volonté, de Théodule Ribot (1883, 1888), revelando que suas leituras enveredam inclusive pelos mais recentes, polêmicos e ousados estudos de psicologia da época.

Alinhavam-se, então, inúmeras referências literárias e filosóficas, costurando citações e menções a autores e obras franceses, entremeados de nomes e títulos estrangeiros, sobretudo britânicos, de Shakespeare a William Morris (discípulo de Ruskin), amealhando, entretempo, clássicos da literatura europeia. Há destaque à menção a Schopenhauer (e a seu Le monde comme représentation et comme volonté, 1819), e ao seu hábito de escrever pautando-se em citações (influência perceptível nos ensaios de Proust, entre outras características e temas do pensamento do filósofo). Com isso, de certa forma, Proust continua ampliando o espectro de sua erudição, ao mesmo tempo em que justifica sua metodologia de trabalho.

Em seguida, Proust remete à leitura dos clássicos. Retornamos à questão inicial, que motivou essa explanação, para uma melhor compreensão do tema do classicismo dentro do contexto da obra proustiana.

Proust compara o gosto de leitura dos grandes escritores com o dos escritores medíocres - martelando na tecla de sua sonoridade interior (relembrando a ideia de Camus sobre a busca obstinada 
do tom pessoal, a obsessão com uma dinâmica interna precisa, premeditada e calculada), e afirma que "a preferência dos grandes escritores é pelos livros dos antigos. Aqueles mesmos que pareceram a seus contemporâneos como os mais "românticos" não liam senão os clássicos (...)" (PROUST, 2011, p. 52). Proust reforça, inicialmente, sem inovar, a ideia da leitura dos clássicos como modelo.

Após vários exemplos, em que explica as preferências pessoais de Victor Hugo e Alphonse Daudet, entre outros, o autor conclui que isso se deve ao fato de o "pensamento contemporâneo, que os escritores e os artistas originais tornam acessível ao público, fazer (...) tão parte deles mesmos que um pensamento diferente os diverte melhor (...) ama-se sempre sair um pouco de si, viajar, quando se lê" (PROUST, 2011, p. 52). Proust assinala que a leitura dos clássicos, portanto, é menos uma recorrência a um modelo, menos um eterno retorno ao mesmo, ou uma repetição, do que um mecanismo para "sair de si". A atemporalidade do clássico permite ao leitor viajar para fora de seu tempo, de seu entorno espacial, e penetrar num alhures diverso, diferente, divertido.

O divertimento ou a distração constituem, porém, apenas um aspecto superficial, e Proust se atém ao teor da diferença:

Mas é outra causa que prefiro, para terminar, atribuir essa predileção dos grandes espíritos pelas obras antigas. É que elas não têm apenas para nós, como as obras contemporâneas, a beleza que nelas soube incutir o espírito que as criou. Elas recebem uma outra beleza ainda mais emocionante do fato de que a sua própria matéria - ouço a língua em que foram escritas - é como um espelho da vida. Um pouco da felicidade que se experimenta quando se passeia numa cidade como Beaune (...) sente-se ainda um pouco dessa felicidade quando se vagueia no meio de uma tragédia de Racine ou de um volume de Saint-Simon. Porque eles contêm todas as formas belas de linguagem abolidas que conservam a lembrança de usos ou de modos de sentir que não existem mais, marcas persistentes do passado ao qual nada do presente se parece e cuja passagem do tempo 
sobre elas não faz senão tornar-lhes mais belas as cores. Uma tragédia de Racine, um volume das memórias de Saint-Simon assemelham-se a belas coisas que não se fazem mais. A linguagem em que foram esculpidas por grandes artistas com uma liberdade que faz brilhar a sua doçura e ressaltar a sua força nativa, nos emociona como a visão de certos mármores, hoje inusitados, que empregavam os trabalhadores de outrora. Sem dúvida, nesses velhos edifícios a pedra conservou fielmente o pensamento do escultor, mas também, graças ao escultor, a pedra, de uma espécie hoje desconhecida, nos foi guardada, revestida com todas as cores que ele soube tirar dela, soube fazer aparecer e harmonizar. Trata-se da sintaxe viva na França do século XVII - e nela costumes e uma forma de pensamento desaparecidos - que amamos encontrar nos versos de Racine. São as próprias formas dessa sintaxe, postas a nu, respeitadas, tornadas belas pelo seu cinzel tão franco e tão delicado que nos emocionam nesses torneios de linguagem familiares até a singularidade e a audácia e dos quais vemos, nos trechos mais doces e ternos, passar como um traço rápido ou voltar atrás em belas linhas quebradas, o brusco desenho. São essas formas acabadas e tomadas à própria vida do passado que vamos visitar na obra de Racine como numa cidade antiga e conservada intacta. Experimentamos diante delas a mesma emoção que sentimos diante dessas formas abolidas, elas também são arquitetura que não podemos mais admirar senão nos raros e magníficos exemplares que nos legou o passado que os modelou (...). (PROUST, 2011, p. 53-55)

O valor do texto, e de sua linguagem, portanto, está na sua qualidade de expressar o tempo em que foi produzido, de resgatar ou, mais radicalmente, de trazê-lo ao presente, de "ressuscitá-lo" (palavra estratégica na tese que Proust vai desenvolver acerca da reminiscência, na Recherche). As obras antigas estão imbuídas e revestidas de uma beleza antiga - seja na arquitetura ou na literatura. A linguagem dos textos clássicos, como os "mármores, hoje, inusitados" é "esculpida" segundo uma sintaxe e um 
pensamento que nos são estranhos, como que estrangeiros. Ler o texto antigo é revisitar o mundo e o tempo em que ele foi produzido, impregnar-se de sua beleza e de seu sentimento.

Essa é uma ideia essencialmente ruskiniana: tanto em La bible d'Amiens quanto nos títulos dedicados à história e à arquitetura de Veneza (Saint Mark's rest, The stones of Venice, entre outros, tão importantes e formadores da própria fascinação de Proust pela cidade, e que se verifica em tantos momentos da Recherche), Ruskin defendeu essa noção de "leitura" da pedra, reconhecimento dos monumentos e dos traços neles deixados pelo tempo, preservação da pedra e dos estragos nela marcados sendo que os estragos, os traços, as marcas, as fissuras e as linhas escrevem, na pedra, histórias que, também elas, segundo Ruskin, devem ser preservadas (há uma grande polêmica ao longo do século XIX quanto à política de preservação do patrimônio histórico, e Ruskin, que domina a vertente inglesa do debate, é antagonista do francês Viollet-le-Duc, que intervém abundantemente sobre os monumentos, restaurando-os segundo o gosto contemporâneo).

Proust recupera essa noção e advoga que "a passagem do tempo sobre as obras antigas torna mais belas as suas cores": de certa forma, é o que fará no seu bal de tête, em que os estragos do tempo sobre os traços dos convidados tornam-se objeto de assombro, mas num belo texto que decanta, justamente, a passagem do tempo; a descrição do envelhecimento dos convivas é a matéria prima, ou bruta, das linhas poéticas do trecho apoteótico de Le temps retrouvé.

Em "Sobre a leitura", Proust compara a leitura de uma peça de Racine com o deambular prazeroso por entre ruelas de uma cidade medieval, porque as palavras e seu agenciamento evocam a lembrança de usos do passado, modos de ver e de fazer de outrora, cuja beleza está, justamente, em se terem perdido, mas "reecontráveis" na ida à fonte, à origem, ao clássico.

Os parágrafos citados acima estão entre os mais expressivos do ensaio de Proust (um estudo completo da complexidade de "Sobre 
a leitura" ultrapassa o nosso escopo, aqui), mas permitem caracterizar o artigo de Proust como, talvez, o grande cadafalso que ergueu para Ruskin: palco onde anuncia a execução/crítica do rei/escritor, mas onde realiza, à avessas, uma apoteose em que o homenageia.

Adotando-se a perspectiva de Camus acerca do classicismo, esse ensaio sobre a leitura é onde Proust, finalmente, enfrenta o "compromisso que o aguarda": expor aos seus pares as suas teses sobre a leitura, seguindo um projeto previamente traçado, com "fixidez de intenção", "obstinação" e "teimosia", depois de muitos esboços e tentativas anunciadas e abandonadas de dar forma a um "sentimento único" e de o fazer "ecoar junto ao leitor".

"Repetição, "monotonia apaixonada", Proust lutou para conseguir levar a cabo os seus projetos de tradução (como se pode constatar à leitura de alguns dos volumes de sua Correspondance, editada em vinte e um tomos pelo especialista Phillip Kolb, pela editora Plomb, 1976-1990), contra as adversidades editoriais, um certo descrédito (quanto ao seu talento) e uma grande concorrência (já havia outros tradutores da obra de Ruskin em plena atividade à época). Mas serviu-se dos dois títulos traduzidos para, nas entrelinhas do texto de Ruskin, escrever o seu próprio texto, os seus próprios ensaios, suas teses, que passaram a ser discutidas, comentadas e, por fim, elogiadas.

Palco do início da reviravolta da carreira de Proust, esse cadafalso permite ao jovem escritor, por assim dizer, executar o velho rei, assenhorar-se de suas palavras e temas, e, com o tempo, estabelecer distância e desvencilhar-se de seu espectro: Ruskin será uma presença marginal, mas inevitável e perceptível, ao longo dos tomos da Recherche, onde paira como uma sombra, um eco persistente, obstinado e teimoso de outrora, de um tempo em que Proust ainda buscava, e descobria, o seu caminho. 


\section{Referências}

CAMUS, A. L'intelligence et l'échafaud. In: CAMUS, A. Oeuvres complètes. Paris: Gallimard, 2006. V. I, p. 894-900.

COMPAGNON, A. Introduction. In: RUSKIN, J. Sésame et les lys. Tradução de Marcel Proust. Bruxelas: Editions Complexe, 1987. p. 7-24.

PROUST, M. Do lado de Swann. Tradução de Fernando Py. [1992]. Disponível em <http://groups-beta.google.com/group/digitalsource>.

PROUST, M. O tempo recuperado. Tradução de Fernando Py. [1997]. Disponível em <http://groups-beta.google.com/group/digitalsource>.

PROUST, M. Sobre a leitura. Tradução de Carlos Vogt. Campinas: Pontes, 2011.

Recebido para publicação em 27 de dezembro de 2013 Aprovado em 24 de março de 2014 